\title{
Hungarian Virtual Computer Museum Using Anaglyph Three-Dimensional Technique MULTIMEDIA
} Zsolt Vidovenyecz ${ }^{*}$

* Gábor Dénes College, Magyarország, Budapest vido.zsolt@gmail.com

\begin{abstract}
The Hungarian virtual computing museum, named Hungarian Old Computers website, is designed to commemorate the Hungarian informatics industry under the Cold War, the heroic age. The paper presents the way to the creation of the computer museum. The most important message of the website for the visitors, who know and use XXIst century-old tools, that the history of computer science is inseparable from the Hungarian cultural history. Without it the culture of the past half century would be truncated.
\end{abstract}

Keywords: virtual museum, 3D anaglyph, computer museum, Hungarian IT history.

\section{INTRODUCTION}

When we hear from a computer that it has about $40 \mathrm{~kg}$ of nearly 100 integrated circuits, its microcontroller is 8bit and its memory is $64 \mathrm{kB}$, then nobody is likely to think of the state-of-the-art technology. There was, however, a time when comprehensible computers with such parameters had an absolute picture of it in our country, in the eastern bloc of the iron curtain.

During my collec- tion work, I was guided by the fact that once I pulled out of the blur of the snow, I could give these machines knowledge and pleasure.

The performance will bring the audience back to the ages, presenting the research and development work prior to the creation of the Hungarian Old Computers ${ }^{1}$ (HOC) website.

\section{HISTORICAL EXHIBITIONS IN HUNGARY}

Getting acquainted with our past is possible in museums. An exhibition of information technology in Hungary, for example in Szeged, is located in Agora in the organization of the Neumann János Computer Society ${ }^{2}$

(NJSZT). This is an outstanding exhibition on an international level. Buda-pest can be visited by the Museum of Art of the Hungarian Technical and Transport Museum ${ }^{3}$.

From 6 April to mid-June 2017, I was able to view my exhibition entitled "The Iron Curtain - The Born of Hungarian Informatics in the Eastern Block" from the

${ }^{1}$ Hungarian Old Computers homepage: www.holdcomputers.com

${ }^{2}$ An exhibition of information technology in Hungary, in Szeged: http://ajovomultja.hu/.

${ }^{3}$ Museum of Art of the Hungarian Technical, Budapest homepage:

https://www.mmkm.hu/hu/tagintezmenyek?tid=3. private collection in the Open Court Program at the Debrecen Court of Appeal ${ }^{4}$ (see Figure 1).

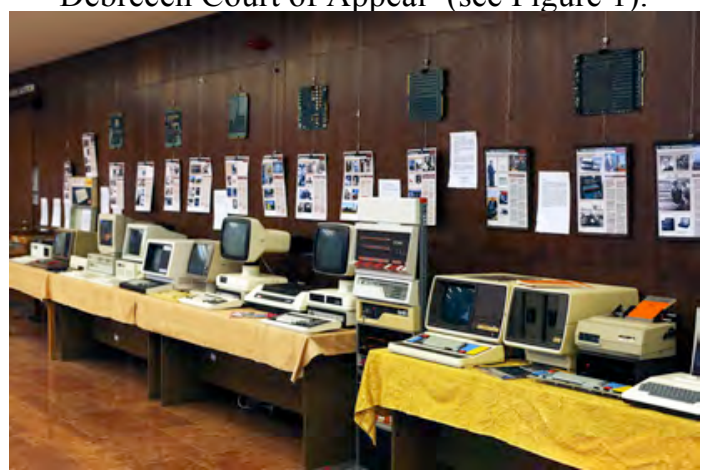

Figure 1: "Iron Curtain Births - Heroes of Hungarian Informatics in the Eastern Bloc" in the lobby of the Debrecen District Court between 6 April 2017 and mid-June

From my exhibition material, the book of the exhibition will be published in the near future in English / Hungarian. In the booklet, they also recognize the light of the Hungarian IT industry in a framework of a kind of paper-based guided tour with 3D-effect images (see Figure 2).

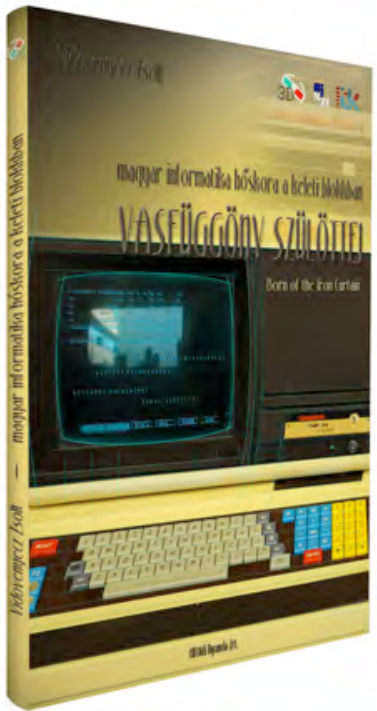

Figure 2: Cover design of publication in the near future "Born of Iron Curtain - Heroes of Hungarian Informatics in the Eastern Bloc"

\footnotetext{
${ }^{4}$ Press release about my exhibition:

http://debrecenitorvenyszek.birosag.hu/sajtokozlemeny/2 0170406/hatteranyag-vasfuggony-szulottei-magyarinformatika-hoskora-keleti-blokkban
} 
Had I miss a smiling story that was on my show and shows how "unknowns" are these machines for today's people. One of the clients arriving at the Debrecen District Court wanted to buy coffee from the Videoton R11 computer of the showroom, because she was looking at coffee machine and looking for where to throw the pot (see Figure 3).

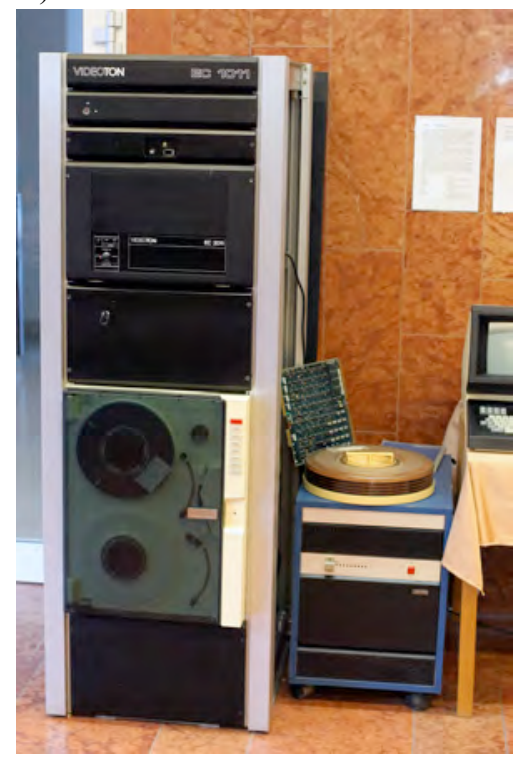

Figure 3: Videoton R11 Megamini Computer, "The Coffee Maker"

Another less joyful episode is the student. Many schools were represented at the exhibition and were popular among students. One of my grammar school teachers was interested in whether or not IT studies included a IT history issue. His answer was very surprising and at once sad: he only contained a question about John Neumann's line item.

During my guided tours I found that the knowledge of the history of information technology was quite incomplete, only a great name was known, and there were few who heard about Kozma and László Kalmár. I was surprised to hear my presentation on the miniflops that her ancestor was BRG MCD-1 from Hungary and was invented by Marcell Jánosi, ahead of everyone in this market.

During my guided tours I found that the knowledge of the history of information technology was quite incomplete, only a great name was known, and there were few who heard about Kozma and László Kalmár. I was surprised to hear my presentation on the miniflops that her ancestor was BRG MCD-1 ${ }^{5}$ from Hungary and was invented by Marcell Jánosi, ahead of everyone in this market.

But how did my collecting / research work begin? This is highlighted in the next chapter.

\section{III. "KNOW THE PURPOSE OF WHOLE THE FUTURE IS INGREDIENT."6}

A very important idea can be attributed to Neumann's Jamaican oeuvre, thanks to the principles of modern computer technology. He said, concisely, that "there is no cure for development". This idea is now becoming more and more important when it comes to expanding the IT and infocommunication tools to an exponential rate. This is why the slogan of the debre-cens exhibition has been to "Learn the past from which the future is rooted". Computing is one of the most important stories of human civilization.

Let's go back in time, a few decades. Compared to the Western countries, some PCs in Hungary were published late in the 1980s. At this time, a professional line of business computers could be called, and computers at home, especially for gaming. They accompanied my childhood to their development, which was also decisive in the future development of life. I was at the center of my relatively early interest in the history of computing. I've been researching and reading a lot about this topic. At the beginning, of course, I was not as conscious as it was today, and my hobbies were limited to home computers because office computer technology was priceless as a private person.

After the embargo on the eastern bloc ceased, the COCOM list was definitively abolished for Hungary on 10 February 1992, and Western technology was free to flow to the country. Within a short time, we also conquered IBM PC XT / AT. Previously non-PCcompatible computers were soon scrapped.

After the deletion of the COCOM list, Five to ten years later, the biggest and most successful collection of Hungarian computers is released, which has been ringing in a few years. Partly because of the fact that a lot of machines have become annihilated, and partly because this activity has become quite popular. Towards the end, there was a situation that "there were more fishermen than fish". Rare and special computers disappeared very quickly.

After doing the research and collecting, after a while, it became clear to me that there was a concept because there were an amazing amount of different types of computers I had to create a framework for my work. My situation was hampered by the fact that my interest was mainly focused on Hungarian-related machines, but these devices were significantly smaller in the market than their Western counterparts.

The collection process has slowed down nowadays, but it can only be increased from a substitution base. The main reason for this is that the market is completely "unleashed", which is gaining momentum over time. If someone is very special, he or she wants a piece of cloth, it must go deep into his pocket. Of course, here is the saying that money is not everything. Fortune is often more than just the story of the next chapter.

\footnotetext{
${ }^{5}$ Marcell Jánosi's MCD-1 cassette floppy: http://ajovomultja.hu/kazettas-floppy-janosi-marcell.
} 


\section{ONE COLLECTOR DREAM COMPLETION}

Every collector's dream is to have a relic of his collection, which is truly unique and truly world-rarity. From this point of view I am lucky myself.

One of the most well-known magazines of the 1980's was the magazine of the Mikro Computing Society of John Neumann. I had one of my favorite readings at that time. The editor of the editorial board was the distinguished figure of Hungarian informatics, Győző Kovács, who participated in the construction of the first Hungarian electron tube computer, M3, on January 21, 1959, at the Hungarian Academy of Sciences (MTA). This magazine was published in 1985/4. number on the cover of an exotic computer that was named Comput-80. ${ }^{7}$ The VBKM Power Generating and System Development Subsidiary has manufactured the GMK license of the Comproject.

Everyone thought it was a phantom: it appeared on the cover of "Mikro" magazine and then disappeared. But it would have been a miracle because it had the prestige at the time of computer manufacturing that every smaller or bigger company had introduced a computer, although in many cases they made only a few copies of it. For example, the aforementioned Comput- 80 can be included here.

A few weeks before the last year's Debrecen exhibition was opened, one of my acquaintances said that I could release old keyboards from her legacy. I found it between the keyboards to find a complete Comput- 80 computer (see Figure 4). For me it is unthinkable for today, what luck has to do with this, as based on the current information, only this piece left the top of this type. It is not found in collectors' circles or in museums. I'm proud that this world-class collection is a great piece of my collection. Gábor Képes, a senior associate of the John Nemann Computer Science Association at the exhibition tour at the opening of the exhibition, gave this machine the title "the Holy Grail of Computers".

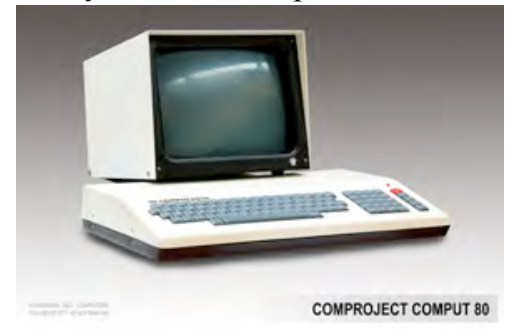

Fre 4: A world rarity of miguy collection, the Comput- 80 computer

But there is not always a chance to go to the museum of real space. Informatics classes and the topic at home would be great if you could look at a virtual computer museum.

\section{GOOD IF BE ON HAND A VIRTUAL MUSEUM}

I feel it is important for an up-and-coming generation to recognize the outstanding domestic engineering potential that, despite the iron curtain's isolation from the state-ofthe-art technologies at that time, has shown significant

\footnotetext{
${ }^{7}$ Microcomputer magazine $1985 / 4$. cover of the number: http://pcvilag.muskatli.hu/irodalom/mm/mm.html.
}

results and contributed to the current technology's current level. Many Hungarians have written their name in international IT history. This is exemplary. Unfortunately, there is currently no permanent exhibition space for my collection, and I'm trying to help my virtual museum.

The legitimacy of the Hungarian Old Computers (HOC) website and the forthcoming book is that, in addition to having no other website and publication that would combine this issue with three-dimensional rendering, it is novel that it is object-oriented. Generally speaking, pages of similar subject matter complement the writing of the object with a photograph of it. If you want to get acquainted with the body, there are two possibilities in our country, as I wrote in chapter II.

However, in many cases it is not justified, and there is not always the possibility to travel to a particular museum. In such a case, " it's good if you have a virtual museum at hand". The 3D anaglyph technology, which enriches the website, is a visual-experience enhancer that does not, in spite of the virtual experience, replace the experience of real museums, but it does bring it closer. But even beyond, since an early computing device can be interesting not only through its external design, but also at the level of internal technical implementation, which is not always possible in museums. However, in the HOC virtual museum, I try not only to get the picture from outside but also from the inside (see Figure 5).

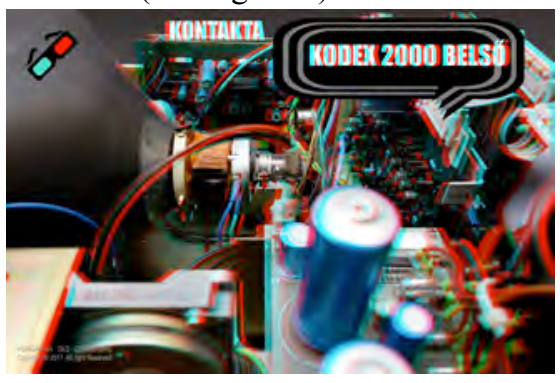

Figure 5: On the Hungarian Old Computers website, computers can be viewed internally in 3D.

The HOC is subject-centric, which means that in most cases, a single object can be viewed in three different external, internal and $3 \mathrm{D}$ views. So the devices can be thoroughly studied. Click on the names of the devices to read the description of the machine. Where I had the opportunity, I would like to present the original brochure.

The HOC also has a list of vectors, NYT biographies and other sources of machinery and information, the content of which is constantly expanding (see Figure 6).

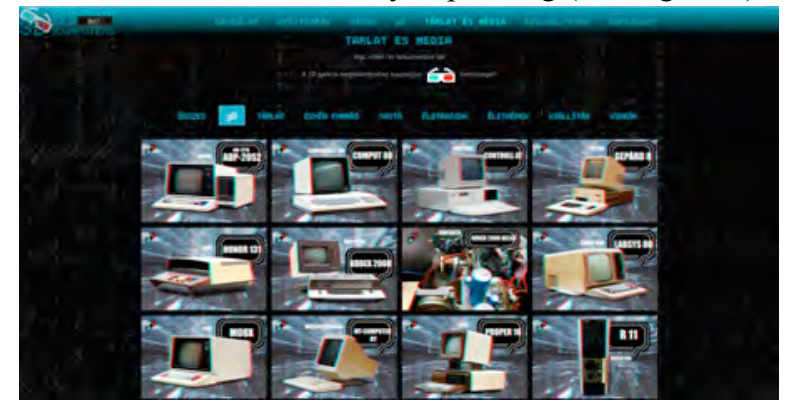

Figure 6: The HOC web page is maintained with the menus, below the $3 \mathrm{D}$ gallery gallery. 
I try to seek fullness in the HOC Museum, but the workable subject is so far away that I'm not even ready. This also shows how productive the industry was for Hungary. With the end of the embargo, the industry has completely transformed, and this form has disappeared. From now on, Western technologies were free to flow to the country. Despite the prohibitions, high-level IT development and production within the KGST were also carried out. The HOC Museum presents the results of this in Hungary. I think that the way home engineers worked for the heroine could not be easy, yet it spoke with all the love of the era, for it was the eldorado for them.

\section{VIRTUAL RECONSTRUCTION}

During my work I found a very exciting challenge that can also go beyond museum visits, which is reconstruction. I started searching for computers that, according to my current information, did not have any copies or high quality photos left. However, there is a sufficient amount of written information available, and at least some drawings, poor quality images to get started.

I found such machines, for example, the MOD 81 computer built by Medicor Works, produced by the Medicor Works and developed by the Budapest University of Technology and Metrology, MMT card system, officially called modular data collector. Unfortunately, none of the museums mentioned above can boast an example and, in my knowledge, it does not have a collection of collections, nor does it have a good quality photo.

During the privatizations, the parent company, Medicor Works, was broken down into several smaller companies. I tried to get information from their successor and get confirmation that the reconstructed MOD 81 was credited with the original product but unfortunately they did not respond to my request. Therefore, this subject is currently available only in the HOC Museum, and currently this is the best photo that describes how the Medicor Mod 81 could be viewed (see Figure 7).

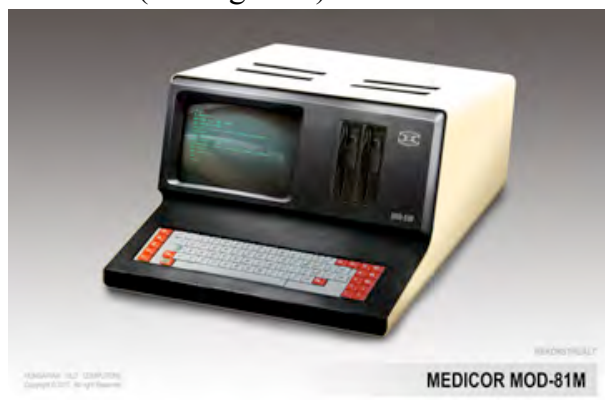

Figure 7: The reconstructed Medicor MOD-81M computer.

The beauty of the reconstruction work lies in the fact that the skeleton, like the archaeologists, was the surviving, especially bad quality photographs (see Figure 8), which, after thorough "cleaning" it, started a graphic work with four different types of home donor computers I've basically rebuilt the computer.

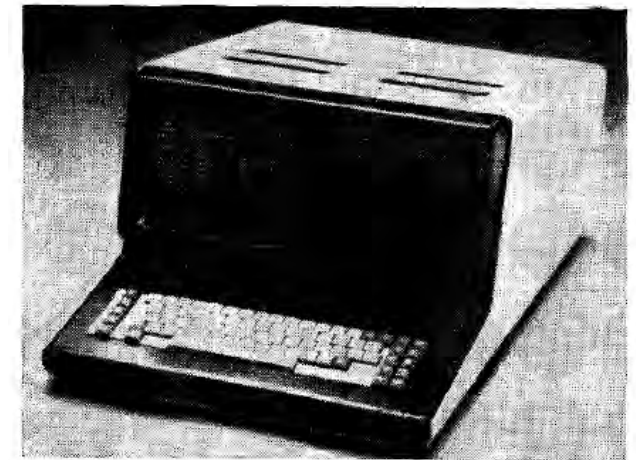

Figure 8: The original photograph of the Medicor MOD-81M computer as a "skeleton".

Of course, the 3D Anaglyph version also features an exhibition (see Figure 9).

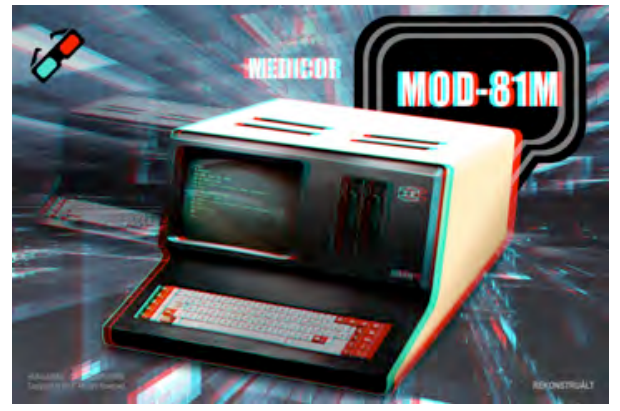

Figure 9: Anaglyph picture of the reconstructed Medicor MOD-81M computer.

Since then, I've been able to find almost the entire MMT modular card system and original documentation for this type, so this will be part of the show and there will not be a black spot in the MOD-81M technical implementation.

Considering the relics of the Hungarian IT industry, it is difficult to show new content. Fortunately, I've been able to use the results of my many years of research and collecting work and I can present such rare, rarity-making objects that can not be found in any other museum or other web site. In any case, this is a positive result, because what's not there is an interest.

\section{FURTHER DEVELOPMENT OF THE VIRTUAL MUSEUM WITH 3D MODELS}

My long-term plans include the technical implementation of the visual experience to the next level in the presentation of objects. In this framework, a collection of nearly one hundred pieces of my collection will be made using a 3D model that will be rotated in the space inside and out. Similarly, you can see, for example, the brands of car brands where you can view the inside of the configured vehicle. This will also be a novel solution to the current virtual museums. 
Summary

They often ask me what is the purpose of my collection or my exhibitions in real and virtual space. What is the most important message of the XXI. century-old devices? I think that what I do is a very serious heritage protection activity whose results should be more widely known. The strength of my collection is that it keeps Hungarian-made products and is therefore an important part of Hungary's technical history. The history of technology is inseparable from the Hungarian cultural history. The toolpath of IT, without computing, the dissemination of the past half a century would be very frustrating.

The introduction of the HOC website and the introduction of my book with the material of my exhibition in Debrecen in the near future can be useful for illustrating and expanding knowledge. Students can study tools that in many cases have been exceptionally beautiful in appearance, and their "shapely" technical solutions make them exciting and discoverable solutions.

\section{ACKNOWLEDGMENTS}

I got encouraging support from the talents of Gábor Dénes for the preparation of my article.

\section{REFERENCES}

[1] Goldstine, Herman H.: A számítógép Pascaltól Neumannig, Müszaki Könyvkiadó, Budapest, 2003. ISBN: 9789631627718 . p. 376

[2] Képes Gábor, Álló Géza: A jövő múltja, Neumanntól az Internetig, Neumann János Számítógép-tudományi Társaság, Budapest, 2013. ISBN: 976-615-5036-06-4 p. 199.

[3] Kovács Győző: A számítógépek technikája, Tankönyvkiadó, Budapest, 1974. ISBN:963-17-0531-5. Tankönyvi szám: 29217. p. 287.

[4] Lukács József: TPA történet lyukszalagtól az informatikáig, KFKI Számítástechnikai Rt., Magyar Tudománytörténeti Intézet, Budapest, 2003. ISBN:9639276324. p. 159.

[5] Von Neumann-Whitman Marina: A marslakó lánya, Európa Kiadó, Budapest, 2016. ISBN: 978-963-405-161-9. p. 334

[6] Kovács Győző: Válogatott Kalandozásaim Informatikában. Történetek a magyar (és külföldi) számítástechnika (h)őskorából, Gamma-Geo Kft-Masszi Kiadó, 2002. ISBN: 9639454222. p. 330.

[7] Mikro Magazin 1984-1990, Neuman János Számítógép-tudományi Társaság, Budapest, 1984-1990.

[8] Salgó Iván: Hardware katalógus - Hazai készülékek, LSI Alkalmazástechnikai Szolgálat, Budapest, 1985. ISBN: 963-592353-8. p. 424.

[9] Dr. Raffai Mária: A hazai számítástechnika története, Alexander alapítvány, Budapest, 2005. p. 56. http://www.sze.hu/ raffai/org/raffai-infotort.pdf. Last visit: 2017.11.12. 